\title{
Enzymatic release of microspheroids containing hydroxyapatite crystals from synovium and of calcium pyrophosphate dihydrate crystals from cartilage
}

\author{
PAUL B. HALVERSON, HERMAN S. CHEUNG, AND DANIEL J. MCCARTY \\ From the Rheumatology Section, Department of Medicine, the Medical College of Wisconsin, 8700 West \\ Wisconsin Avenue, Milwaukee, Wisconsin 53226, USA
}

SUMMARY Incubation of minced, focally calcified, chondromatosis tissue obtained at operation from a patient with Milwaukee shoulder (rotator cuff defect and glenohumeral osteoarthritis associated with synovial fluid, hydroxyapatite crystals in microspheroidal masses, collagenase, and neutral protease) with partially purified mammalian synovial cell collagenase released masses of hydroxyapatite crystals of the same size as those originally found in the patient's synovial fluid. Incubation of mineral articular cartilage obtained from a shoulder joint at arthroplasty for a destructive arthropathy in a patient with generalised calcium pyrophosphate dihydrate (CPPD) crystal deposition with partially purified synovial cell collagenase freed CPPD crystals from their matrix. These data are compatible with a previously postulated mechanism linking microcrystals to destructive arthropathies, that is, crystal endocytosis by synovial cells stimulating collagenase secretion with subsequent enzymatic crystal 'strip-mining', releasing additional crystals into the synovial fluid in a self-perpetuating cycle.

Destructive arthropathies have been associated with both hydroxyapatite (HA) ${ }^{1}$ and calcium pyrophosphate dihydrate (CPPD) ${ }^{2}$ crystal deposition in articular tissues. Glenohumeral osteoarthritis, rotator cuff defects, and synovial fluid containing HA crystals in microspheroidal masses, collagenase, and neutral protease are the cardinal features of the recently described 'Milwaukee shoulder syndrome'. ${ }^{134}$ The concentration of HA crystals in synovial fluid from the shoulder joints of 2 patients, as estimated by a $\left({ }^{14} \mathrm{C}\right)$ ethane-l-hydroxy-l, l-diphosphonate (EHDP) binding assay, were remarkably constant over many months,${ }^{35}$ suggesting that the crystal concentration in these fluids is under homoeostatic control. We therefore postulated the existence of: (1) mechanism(s) of crystal release from joint tissues into synovial fluid, and (2) mechanism(s) of crystal removal from synovial fluid. We have recently shown that CPPD crystals injected into rabbit joints are taken up by fixed macrophage-like synovial cells. ${ }^{6} 7$ Both $\mathrm{HA}$ and calcium pyrophosphate dihydrate (CPPD) are endocytosed by synovial cells in monolayer culture, and such

Accepted for publication 18 August 1981.

Correspondence to Dr P B Halverson uptake is associated with augmentation of basal collagenase and neutral protease secretion. ${ }^{8}$

Postulated mechanisms leading to crystal release from preformed tissue deposits into the joint space include: (a) shedding due to factors leading to increased crystal solubility; (b) trauma, such as microfractures of subchondral bone; and (c) enzymic attack on the organic matrix of cartilage or synovium leading to crystal 'strip-mining'. ${ }^{9}$ The last mechanism has been tested experimentally and is the subject of this report.

\section{Materials and methods}

Collagenase was obtained from human rheumatoid synovial cell cultures and assayed as described elsewhere. ${ }^{8}$ By the method of Wize $50 \%$ saturated $\left(\mathrm{NH}_{4}\right)_{2} \mathrm{SO}_{4}$ was used to precipitate collagenase from conditioned media. ${ }^{10}$ It was then passed through a Sephadex G-200 column. Fractions containing collagenase eluted with markers that suggested an approximate molecular weight of 33000 daltons. Fractions containing enzyme were concentrated with Aquacide (Calbiochem-Behring Corp., LaJolla, 
$\mathrm{CA}$ ), dialysed against $0.05 \mathrm{M}$ Tris- $\mathrm{HCl}$ buffer containing $0.1 \mathrm{M} \mathrm{NaCl}$ and $0.005 \mathrm{M} \mathrm{CaCl}_{2}$, and chromatographed on DEAE-Sephadex A-50. Collagenase-containing fractions were dialysed against distilled water and lyophilised. The specific activity of the partially purified enzyme was 85 units/ $\mathrm{mg} \mathrm{(1}$ unit $=1 \mu \mathrm{g}$ collagen gel digested per minute at $\left.37^{\circ} \mathrm{C}\right)$.

Tissues. Synovium obtained from the right shoulder of a patient (AB) by surgical synovectomy showed typical chondromatosis grossly and by light and electron microscopic study. ${ }^{3}$ Specimen radiography showed multiple areas of calcifications. These areas were composed of masses of needle-shaped crystals which by $x$-ray energy dispersive analysis showed a molar $\mathrm{Ca} / \mathrm{P}$ of $1 \cdot 6$, compatible with $\mathrm{HA}$. This tissue was stored at $-70^{\circ} \mathrm{C}$ until use. Tissue samples containing calcifications were dissected from the thawed specimen and used experimentally.

Hyaline articular cartilage was obtained from the left shoulder joint of a 55-year-old white man with generalised calcium pyrophosphate dihydrate crystal (CPPD) deposition during arthroplasty for a destructive arthropathy. This tissue was stored at $-20^{\circ} \mathrm{C}$ until use.

Both synovium and cartilage samples were minced with a scalpel into pieces approximately $1-2 \mathrm{~mm}$ in diameter, randomised to provide samples of about $100 \mathrm{mg}$ wet weight (range 99 to $102.5 \mathrm{mg}$ ), and incubated for 1 hour in $4 \mathrm{ml}$ of sterile $50 \mathrm{mM}$ Tris chloride buffer, $\mathrm{pH} 7 \cdot 5$ containing $3 \mathrm{mM}$ calcium chloride, $2 \%$ penicillin-streptomycin-fungizone (MS Bioproducts, Walkersville, MD) and $100 \mu \mathrm{g} / \mathrm{ml}$ gentamycin (Schering Corp., Kenilworth, NJ). This mixture was stirred continuously but gently at $20^{\circ} \mathrm{C}$ with a magnetic stir bar and centrifuged for 5 minutes in an IEC Clinical Centrifuge (International Equipment Co., Needham, CA).

Incubations. Pellets were resuspended in $2 \mathrm{ml}$ of buffer alone or buffer containing $0 \cdot 2 \%(\mathrm{w} / \mathrm{v})$ bacterial collagenase (specific activity $=148 \mu / \mathrm{mg}$ Millipore Corp., Freehold, NJ). Other pellets of synovium were resuspended in $2 \mathrm{ml}$ buffer containing $0.05 \%(\mathrm{w} / \mathrm{v})$ mammalian collagenase. Minced pieces of cartilage were resuspended in $2 \mathrm{ml}$ buffer containing $0 \cdot 1 \%$ (w/v) mammalian collagenase. These were gently stirred for 72 hours (synovium) or 96 hours (cartilage) at $37^{\circ} \mathrm{C}$. After incubation, the contents of each tube were passed through a $44 \mu \mathrm{m}$ sized Nitex filter (Tetko, Inc., Elmsford, NJ). Each tube was washed 3 $x$ with $1 \mathrm{ml}$ of buffer and filtered similarly. The filtrates were centrifuged at $38000 \mathrm{~g}$ for 30 minutes (Sorvall RC-2B, Norwalk, CT). Supernatants were decanted and discarded and pellets were resuspended in $5 \mathrm{ml}$ phosphate buffered saline (PBS). After centrifugation they were again resuspended in $1 \mathrm{ml}$ PBS.
Crystal assay. Released materials from synovial samples were studied for the presence of HA crystals by the $\left({ }^{14} \mathrm{C}\right)$ EHDP binding assay described previously. ${ }^{11}$ Pellets obtained from this assay were further analysed by scanning electron microscopy (SEM) and $x$-ray energy dispersive analysis or transmission electron microscopy, also as described previously. ${ }^{3}$ Released materials from the cartilage samples were dissolved in $2 \mathrm{ml}$ of $0.1 \mathrm{~N} \mathrm{HCl}$ and analysed for calcium by atomic adsorption spectrophotometry and for phosphorus by the Fiske and Subba Row method. ${ }^{12}$ Material from one sample was also examined by scanning electron microscopy and energy dispersive analysis.

\section{Results}

\section{SYNOVIUM}

$\left({ }^{14} \mathrm{C}\right)$ EHDP binding of material released by mammalian collagenase was (mean \pm SEM) $9 \cdot 9 \pm 2.5 \mu \mathrm{g}$ $\mathrm{HA} \mathrm{ml^{-1 }}$ by bacterial collagenase $10 \cdot 3 \pm 1 \cdot 7 \mu \mathrm{g} \mathrm{HA}$ $\mathrm{ml}^{-1}$ and by buffer alone $2 \pm 0 \cdot 6 \mu \mathrm{g} \mathrm{HA} \mathrm{ml}^{-1}$ (Table 1). A few HA crystals have been mechanically released by stirring. There was no visible change in synovial particle size in the control tubes during the incubation, while in the tubes containing either enzyme the size of the tissue pieces was visibly diminished.

Scanning electron microscopy of digested pellets showed spheroidal particles of the type observed previously in joint fluids from patients with the Milwaukee shoulder syndrome ${ }^{3}$ (Figs. 1a and b). The mean $( \pm$ SEM) diameter of representative particles released by mammalian collagenase was $12.9 \pm 0.9$ $\mu \mathrm{m}$, very close to the mean diameter $(13 \cdot 6 \pm 1 \cdot 3)$ noted in the joint fluids from patient $\mathrm{AB}^{3}$ (table 2). The mean diameter of particles released by bacterial collagenase was $9 \cdot 3 \pm 0 \cdot 6 \mu \mathrm{m}$. Transmission electron microscopy showed clumps of needle-shaped crystals identical in size to those seen both intracellularly and in the extracellular matrix in the whole synovium ${ }^{3}$ (Fig. 2).

Cartilage. The calcium and phosphorus content of

Table $1 \quad\left({ }^{14} \mathrm{C}\right)$ EHDP binding ( $\mu \mathrm{g} \mathrm{ml}^{-1}$ of HA standard) of filtrate from synovium of patient $A B$

\begin{tabular}{|c|c|c|c|c|}
\hline \multirow[t]{2}{*}{ Trearment } & \multicolumn{3}{|c|}{ Calcified synovial specimens } & \multirow{2}{*}{$\begin{array}{l}\text { Mean士 } \\
\text { SEM }\end{array}$} \\
\hline & No. 1 & No. 2 & No. 3 & \\
\hline $\begin{array}{l}\text { Bacterial } \\
\text { collagenase }\end{array}$ & $\begin{array}{l}11 \\
16 \\
16\end{array}$ & $\begin{array}{l}11 \\
13\end{array}$ & $\begin{array}{l}4 \\
5 \\
6\end{array}$ & $10 \cdot 3 \pm 1 \cdot 7$ \\
\hline $\begin{array}{l}\text { Mammalian } \\
\text { collagenase }\end{array}$ & $\begin{array}{l}23 \\
17 \\
10\end{array}$ & $\begin{array}{r}4 \\
13\end{array}$ & $\begin{array}{l}4 \\
4 \\
6\end{array}$ & $9 \cdot 9 \pm 2 \cdot 5$ \\
\hline Control & $\begin{array}{l}4 \\
3 \\
1\end{array}$ & $\begin{array}{l}0 \\
0\end{array}$ & $\begin{array}{l}3 \\
1 \\
4\end{array}$ & $2 \cdot 0 \pm 0 \cdot 6$ \\
\hline
\end{tabular}




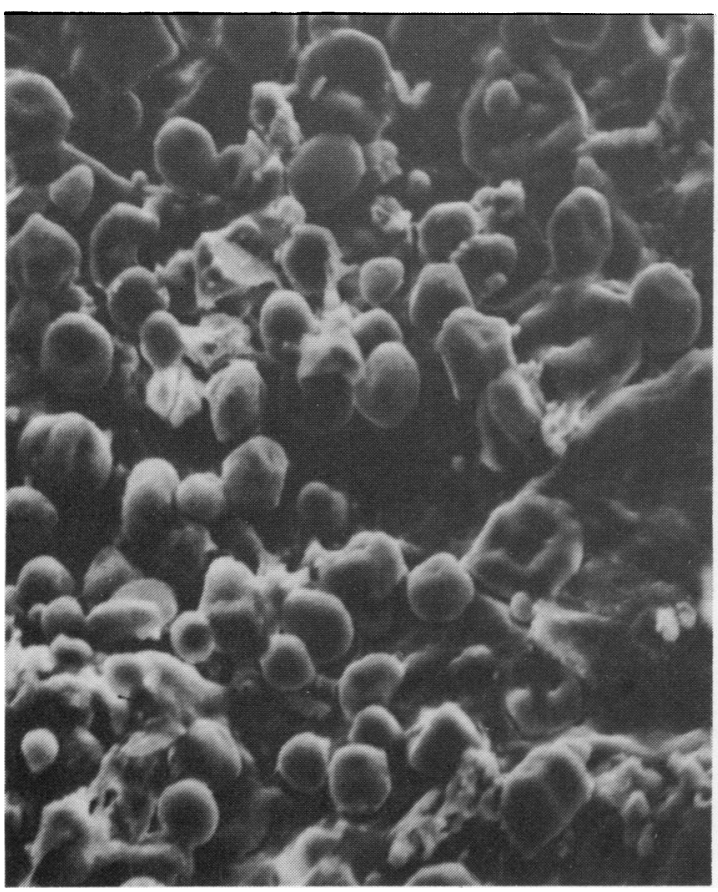

Fig. 1a

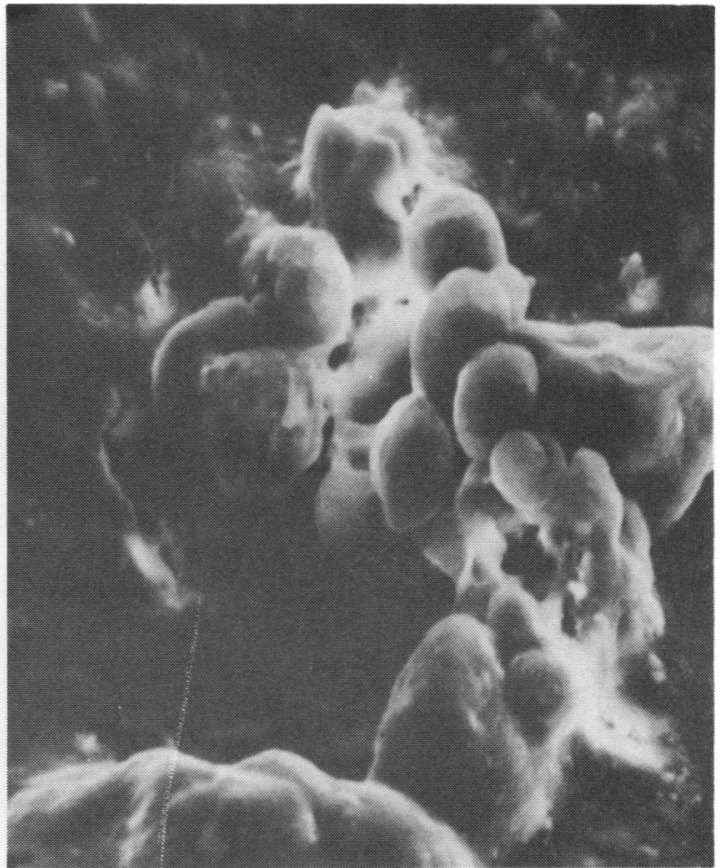

Fig. 1b

Fig. 1 (a) Typical clump of microspheroidal particles containing calcium and phosphorus in a ratio consistent with HA in pellet of synovial tissue treated with bacterial collagenase. (SEM, $\times 773)$. (b) Typical microspheroidal particles in pellet of synovial chondromatosis tissue treated with mammalian collagenase. $(S E M \times 386)$.

Table 2 Dimensions and molar calcium/phosphorus of microspheroids released from synovium of patient $A B$

\begin{tabular}{|c|c|c|}
\hline Treatment & $\begin{array}{l}\text { Mean particle } \\
\text { diameter } \\
\pm S E M(\mu \mathrm{m})(n=9)\end{array}$ & $C a / P^{*},(n=6)$ \\
\hline $\begin{array}{l}\text { Bacterial collaenase } \\
\text { Mammalian collagenase } \\
\text { Control }\end{array}$ & $\begin{array}{l}9 \cdot 3 \pm 0 \cdot 6 t \\
12 \cdot 9 \pm 0 \cdot 9 t \\
\text { None seen }\end{array}$ & $\begin{array}{l}1.6 \pm 0.07 \\
1.6 \pm 0.05\end{array}$ \\
\hline
\end{tabular}

*Mean \pm SEM; HA standard showed $1 \cdot 7 \pm 0 \cdot 02 ; n=6$.

+Not statistically different by Spearman rank correlation. the Nitex filtrates of calcified cartilage is given in Table 3. The molar $\mathrm{Ca} / \mathrm{P}$ was close to unity, consistant with that of CPPD crystals. A scanning electron micrograph of the particulate matter in a filtrate is shown in Fig. 3. The molar $\mathrm{Ca} / \mathrm{P}$ of these crystals by energy dispersive analysis also approximated to unity.

The calculated crystal mass released from cartilage by either bacterial or mammalian collagenase was nearly identical and approximated to $1 \mathrm{mg}$ per 100 $\mathrm{mg}$ of wet weight of tissue. An average of only 0.03 $\mathrm{mg}$ was released by incubation with buffer alone.

Table 3 Calcium and phosphorus content of material released from calcified cartilage

\begin{tabular}{|c|c|c|c|c|c|}
\hline Treatment & Sample & Calcium $(m M)$ & Phosphorus (mM) & $\mathrm{Ca} / \mathrm{P}$ & Mean $\pm S E M$ \\
\hline Bacterial collagenase & $\begin{array}{l}1 \\
2 \\
3\end{array}$ & $\begin{array}{l}3 \cdot 62 \\
3 \cdot 11 \\
4 \cdot 40\end{array}$ & $\begin{array}{l}3 \cdot 67 \\
3 \cdot 38 \\
4 \cdot 59\end{array}$ & $\begin{array}{l}0.99 \\
0.92 \\
0.96\end{array}$ & $0.96 \pm 0.02$ \\
\hline Mammalian collagenase & $\begin{array}{l}4 \\
5 \\
6\end{array}$ & $\begin{array}{l}4 \cdot 42 \\
2 \cdot 27 \\
2 \cdot 48\end{array}$ & $\begin{array}{l}4 \cdot 58 \\
2 \cdot 29 \\
2 \cdot 79\end{array}$ & $\begin{array}{l}0.97 \\
0.99 \\
0.89\end{array}$ & $0.95 \pm 0.03$ \\
\hline Buffer alone & $\begin{array}{l}7 \\
8 \\
9\end{array}$ & $\begin{array}{l}0.212 \\
0.273 \\
0.580\end{array}$ & $\begin{array}{l}\text { None } \\
\text { None } \\
0.64\end{array}$ & 0.91 & \\
\hline
\end{tabular}




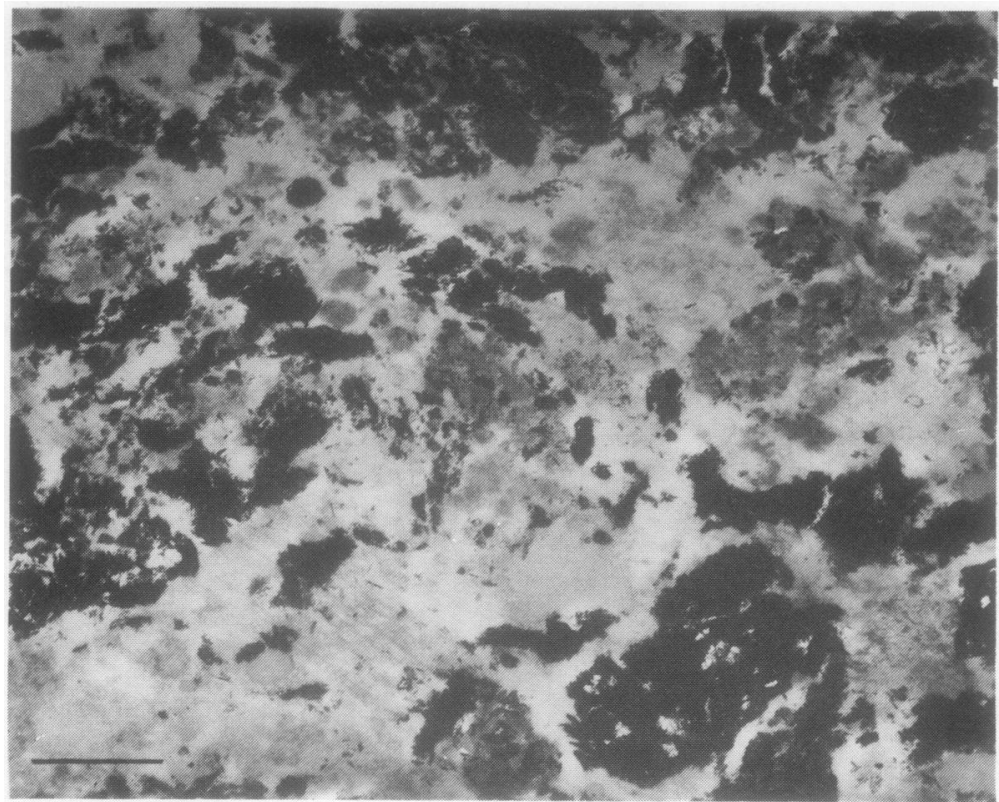

Fig. 2 Masses of needle-shaped crystals in pellet of synovial chondromatosis tissue treated with mammalian collagenase.

(Transmission EM, × 13 000; horizontal line indicates $1 \mu \mathrm{m}$ ).

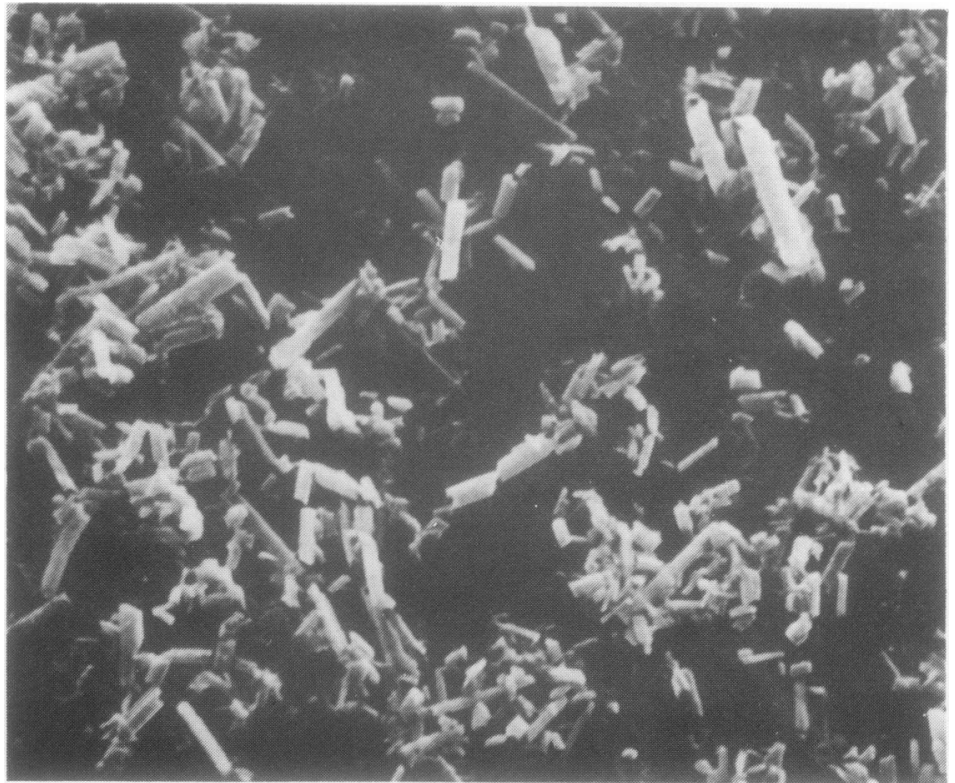

Fig. 3 Particles in the filtrate of calcified cartilage treated with collagenase showed the typical morphology of CPPD $D_{i}$ crystals. (SEM, × 1990). 


\section{Discussion}

In the Milwaukee shoulder syndrome we postulated a pathogenetic cycle whereby the microspheroidal clumps of HA crystals in joint fluid are phagocytosed by synovial lining cells, stimulating their secretion of collagenase and neutral protease. ${ }^{1}$ Additional HA crystal-containing microspheroids are then released from the collagenous network that entraps them by 'enzymatic strip-mining'. This aspect of the postulated cycle is supported by the data presented here, showing that mammalian collagenase released HA crystals from synovium in masses of an identical size by scanning electron microscopy to those previously found in the joint fluid from the same patient. ${ }^{3}$

Transmission electron microscopic examination of synovial chondromatosis, found at surgery in this patient, showed calcific masses with free access to the joint space through areas denuded of synovial cells. ${ }^{4}$ Although the underlying synovial pathology is not known in the other affected shoulder joints, the finding of particulate collagens, types I, II, and III in the joint fluids, all of which occur in chondromatosis, ${ }^{413}$ and the prominent 'filling defects' seen in the arthrograms of 3 other shoulders, typical of the intraarticular loose bodies of chondromatosis, suggests the likely existence of this condition.

The release of CPPD crystals, embedded in proteoglycan and entrapped in a collagenous matrix within hyaline articular cartilage, ${ }^{14}{ }^{15}$ is also compatible with an earlier postulate of enzymatic stripmining. ${ }^{16}$ Such a mechanism may account for the finding of CPPD crystals in the fluid from joints affected by other inflammatory conditions, such as sepsis or gout. As CPPD crystals are cleared from the joint space by synovial cell endocytosis, ${ }^{7}$ and as their half-life in human synovium is measured in months, ${ }^{6}$ the augmentation of proteolytic enzyme secretion may be of sufficient intensity and duration to account for the cartilage degeneration and destructive arthropathies often associated with these particles. ${ }^{215}$ Lastly, enzymatic release of crystals from tissue deposition may play a role in the initiation and perpetuation of CPPD crystal induced acute inflammation.

The shedding of crystals into the joint space which we envisage may be multifactorial. Perhaps increased crystal solubility due to decreased ionised calcium or inorganic pyrophosphate levels in ambient joint fluid initiates crystal release, while proteolytic enzymes from synovial cells and/or polymorphonuclear leucocytes accelerate the rate of release beyond the point of compensation by synovial cell crystal uptake.
The authors thank Mrs Janine Struve for her excellent technical assistance.

This work was supported by USPHS grants AM-26062 and AM-05621.

\section{References}

${ }^{1}$ McCarty D J, Halverson P B, Carrera G F, Brewer B J, Kozin F. 'Milwaukee shoulder': association of microspheroids containing hydroxyapatite crystals, active collagenase and neutral protease with rotator cuff defects. I: clinical aspects. Arthritis Rheum 1981; 24: 464-73.

2 Menkes C S, Simon F, Delrieu F, Forest M, Delbarre F. Destructive arthropathy in chrondrocalcinosis articularis. Arthritis Rheum 1976; (suppl) 19: 329-48.

3 Halverson P B, Cheung H S, McCarty D J, Garancis J, Mandel N. 'Milwaukee shoulder': association of microspheroids containing hydroxyapatite crystals, active collagenase and neutral protease with rotator cuff defects. II. synovial fluid studies. Arthritis Rheum 1981; 24: 474-83.

4 Garancis J D, Cheung H S, Halverson P B, McCarty D J. 'Milwaukee shoulder': association of microspheroids containing hydroxyapatite crystals, active collagenase and neutral protease with rotator cuff defects. III. morphologic and biochemical studies of an excised synovium showing chondromatosis. Arthritis Rheum 1981; 24: 484-91.

5 McCarty D J, Cheung H S, Halverson P B, Garancis J C. 'Milwaukee shoulder syndrome': microspherules containing hydroxyapatite, active collagenase and neutral protease in patients with rotator cuff defects and glenohumeral osteoarthritis. Semin Arthritis Rheum 1981; 11: 119-21.

${ }^{6}$ McCarty D J, Palmer D W, Halverson P B. Clearance of calcium pyrophosphate dihydrate (CPPD) crystals in vivo I. studies using ${ }_{169}^{16 b}$ labelled triclinic crystals. Arthritis Rheum 1979; 22: 718-27.

${ }^{7}$ McCarty D J, Palmer D W, James C. Clearance of calcium pyrophosphate dihydrate (CPPD) crystals in vivo II. studies using triclinic crystals doubly labelled with ${ }^{45} \mathrm{Ca}$ and ${ }^{85} \mathrm{Sr}$. Arthritis Rheum 1979; 22: 1122-31.

${ }^{8}$ Cheung H S, Halverson P B, McCarty D J. Release of collagenase, neutral protease and prostaglandins from cultured mammalian synovial cells by hydroxyapatite and calcium pyrophosphate dihydrate crystals. Arthritis Rheum in press.

- McCarty D J. Pathogenesis and treatment of crystal-induced inflammation. In: McCarty D J, ed. Arthritis and Allied Conditions. 9th ed. Philadelphia: Lea and Febiger, 1979; 1245-61.

10 Wize J. Latent collagenase from rheumatoid synovial fluid. Biochim Biophys Acta 1980; 615: 199-207.

11 Halverson P B, McCarty D J. Identification of hydroxyapatite crystals in synovial fluid. Arthritis Rheum 1979; 22: 389-95.

${ }^{12}$ Fiske C H, Subba Row Y. The colorimetric determination of phosphorus. J Biol Chem 1925; 66: 375-400.

13 Ryan L M, Cheung H S, Schwab J P, Johnson R P. Collagen types in synovial chondromatosis. Submitted for publication.

${ }^{14}$ Reginato A J, Schumacher H R, Martinez V A. The articular cartilage in familial chondrocalcinosis. Light and electron microscopic study. Arthritis Rheum 1974; 17: 977-92.

15 McCarty D J. Calcium pyrophosphate dihydrate crystal deposition disease: pseudogout, articular chondrocalcinosis. In: McCarty D J. ed. Arthritis and Allied Conditions. 9th ed. Philadelphia: Lea and Febiger, 1979: 1276-97.

${ }_{16}$ Smith J R, Phelps P. Septic arthritis, gout, pseudogout and osteoarthritis in the knee of a patient with multiple myeloma. Arthritis Rheum 1972; 15: 89-96. 